\title{
A Comprehensive Review of Sheep and Goat Pox Viruses: Perspective of Their Epidemiology and Economic Importance in Egypt
}

Mona R. Fares*, Mohamed Fawzy**, Momtaz A. Shahin*, Mohamed S. Elshahidy**

*Department of Virology, Animal Health Research Institute (AHRI), Dokki,

Giza 12611, Egypt **Department of Virology, Faculty of Veterinary

Medicine, Suez Canal University, Ismailia 41522, Egypt

**Corresponding author: Mohamed Fawzy,

Mohamed_mohamed4@vet.suez.edu.eg

\begin{abstract}
:
Sheep and goat pox (SGPV) is contagious viral disease of small ruminant animals. It is characterized by fever, anorexia, depression, inflammation of the mucous membranes of the eyes and nose, respiratory distress with appearance of pox lesions on areas devoid of wool and hair such as checks, lips, nostrils, inner aspect of the thigh and beneath the tail, also the size of superficial lymph nodes was larger than normal. The objective of this article was to review the epidemiology and economic importance of sheep and goat pox. The causative agent of Sheep and goat pox is SGPV of Subfamily, Chordopoxvirinae, family Poxoviridae, genus Capripoxvirus. SGPV has worldwide distribution and endemic throughout southwest and central Asia, northern and central Africa, and Middle East countries including Egypt. SGPV produce unusual economic loss due to high morbidity, mortality rate, reduction in milk and meat production, abortions, poor wool and skin quality and as a result of trade restrictions. Survival of SGPV in external environment may reach about 6 months. The virus inactivated by sun light and heat, sensitive to detergents as sodium dodecyl sulphate and ether $20 \%$, chloroform and formalin $1 \%$. The diseases are more severe in young animals than adults with mortalities up to $100 \%$. Control of the disease depends on early detection and notification, restriction of animals' movement, culling of affected and in-contact animals, and ring vaccination with inactivated vaccine.
\end{abstract}

\section{Introduction}

Sheep and goats are seeming to be one of the most significant economic sources in Egypt, because of high quality meat and wool production. Sheep and goats are raised either by small scale farmers 
or in village flocks. SGPV are responsible for the significant economic impact in animal industry in Egypt (Khameis et al., 2018). Young animals, Flock sizes, number of adult animals affected and number of days of illness make great influence on economic losses (Senthilkumar et al., 2010). The disease is one of the 15 animal pathogens listed by OIE (USDA, 2002). All members of Capripoxviruses are antigenically related to each other. There are close antigenic and genetic relationship between SPPV and GTPV (Fenner et al., 1996). SGPV has worldwide distribution and endemic throughout southwest and central Asia, northern and central Africa, and Middle East countries including Egypt (Maksutov et al., 2013).

The virus transmitted through aerosols and/or close contact with infected animals, indirect means such as contamination of cuts and abrasions (Kitching and Carn, 2004). Most important causes for distribution of SGPV are poor conditioned animals, overstock, poor feeding, insufficient management, and incorrect use of vaccination program (Zangana and Abdullah, 2013). SGPV characterized by appearance of pox lesions as papular, pustular, scab stages on areas devoid of wool such as checks, lips, nostrils, inner aspect of the thigh and under the tail and enlargement of superficial lymph nodes (Diallo and Viljeon 2007). post-mortem lesions appeared congestion, hemorrhage, edema, vasculitis, and necrosis in skin layers involving epidermis, dermis, and, in severe cases, extend into the nieghbouring muscule (Ausvetplan, 1996).

Because of the close antigenicity between SPPV and GTPV, it is difficult to differentiate these pathogens using virus isolation and serological tests (Balinisky et al., 2008). Polymerase chain reaction (PCR) followed by sequencing is considered a rapid, sensitive and good specific technique on detection and differentiation of SPPV and GTPV based on the open reading frame genes and also used for genotyping (Zhu et al., 2013). Outbreaks of the disease can be controlled by ring vaccination, quarantine measures, slaughter and trade restriction (Hailat et al., 1994).

\section{Etiology}

SGPV belong to the subfamily Chordopoxvirinae, family Poxviridae, and the genus Capripoxvirus (ICTV, 2012). Pox virus is the largest virus with brick shaped morphology of 170 to $260 \mathrm{X}$ 300 to 450 -nm-diameter capsid. Its genome is double-stranded DNA, non-segmented, and linear. A false lipid envelope surrounds the genome (Kitching, 2004). The size of the genome is approximately 150 $\mathrm{kbp}$ and it contains at least 147 putative genes (Tulman et al., 2002). The optimum temperature for the growth of SGPV is $37{ }^{\circ} \mathrm{C}$ 
(Soman and Singh, 1981). The virus is inactivated by temperature at $56^{\circ} \mathrm{C} / 2$ hours; $65^{\circ} \mathrm{C} / 30$ minutes (OIE, 2000). A pH of 8.2 is optimum for growth of SGPV (Soman and Singh, 1981). Survival of SGPV in external environment may reach about 6 months. They are inactivated by sun light and heat (Davies, 1981). Virus also found on the wool or hair for as long as 3 months after infection (Sharma et al., 1988). SGPV inactivated by drying, freezing, thawing, and remain viable for months in the lyophilized state (Sharma et al., 1988). SGPV is sensitive to detergents (e.g. sodium dodecyl sulphate) and to ether $(20 \%)$, chloroform, formalin (1\%), and sodium hypochlorite (2$3 \%)$, iodine compounds (1:33 dilution), Virkon ${ }^{\circledR} 2 \%$, quaternary ammonium compounds $(0.5 \%)$ (OIE, 2014).
Geographical distribution

Global distribution of sheep and goat pox virus

Global distribution of SGPV persisted in North and Central Africa, Middle Eastern countries, Asia and the former Soviet Union were predicted in Figure 1. SGPV is endemic in Africa, China, Turkey, Pakistan, Iraq, Afghanistan and Indian subcontinent. Sporadic outbreaks found in southern Europe (OIE, 2010). SGPV is endemic in Africa (except it's southern part), Asia, the Middle East, and Turkey with sporadic outbreaks in Greece and some eastern European countries (Diallo and Viljoen, 2007). SGPV is absent from Central and Western Europe for many years. But there are recent outbreaks of SGP occur in southeastern Europe, there is prospect for further spread of these CaPVs to the Europe (AHA, 2011).

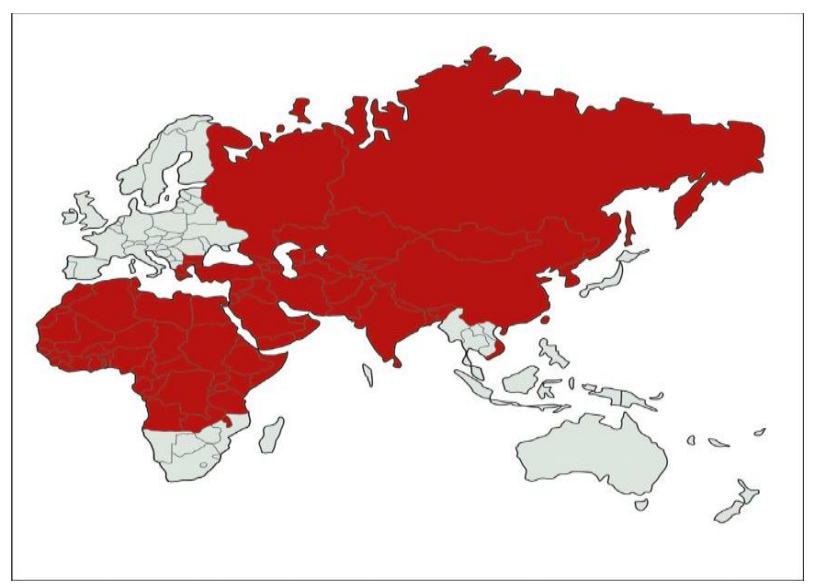

Fig (1): Distribution of SPPV and GTPV in Africa, Middle East countries and Europe (OIE WAHID2015). 
Distribution of sheep and goat pox virus in Egypt

Cases of infected animals from farms at different provinces of upper Egypt (Menia Governorate) and Lower Egypt (Kafr EL Sheikh, Monfia, and Dumiat Governorates) were appeared between November 2006 to October 2007 (Amal et al., 2008). In Hawamdia township of Giza Governorate, Egypt, an outbreak of sheep and goat pox virus flock during 2014 and 2015 was resident (Mahmoud and Khafagi , 2016). Distribution of sheep and goat pox virus. An outbreak of SPPV of nonvaccinated flock of sheep was recorded in Kafr Shalshamoun, Menya Al Qamh, Sharkia, Egypt in April 2017 (Eman et al., 2018).

Economic importance of sheep and goats in Egypt:

Sheep and goats are important component of Egyptian livestock production represent about $30 \%$ of the country's total agricultural income. So, they comprise great position in Egypt's food security plan. More than 2.34 million head of sheep produced red meat represent about $7.4 \%$ of all red meat production in Egypt was reported in 2017 (FAO STAT, 2018).

Number of sheep in Egypt now is about 5.69 million head which has been increased in number due to their ability to graze and their low need for less concentrate, while number of goats is less than sheep and about 4.35 million head. Sheep and goats are raised either by small scale farmers or in village flocks. Carcass weight was estimated by about 30.9 kilograms. sheep give about 99,322 tons of total milk production. Sheep have the ability to travel long distances during grazing and to withstand hard environmental conditions also are more efficient in converting nondense food to meat, milk and wool. So that, sheep are able to produce meat and milk without consuming large quantities of feed concentrates when compared with cattle or buffaloes (Elshazly and Youngs, 2019), Sheep and goats are seem to be one of the most significant economic sources in Egypt, because of high quality meat and wool production.

SGPV is highly contagious viral disease of small ruminants, responsible for the significant economic losses of animal industry in Egypt (Khameis et al., 2018), the disease produce limitation in international trade of animals and animal product (OIE 2008 a), and remarkable economic loss due to high morbidity, mortality rate, reduction milk and meat production, abortion, poor wool and low skin quality (Yeruham et al., 2007).

This disease is lethal in newly imported animal, but may be mild in local inbred animals from endemic area. The outbreak of sheep and goat pox may cause severe economic losses in small ruminant animal industries (Nandi et al., 1999). 
Trade, importation, exportation and intensive production of animals can be affected by SGP disease. Factors affecting the economic losses related to Sheep Pox are size of flock, number of adult animals and number of days of illness (Garner and Lack, 1995).

Processing operation that occurs to hides and skins either by salting treatment or drying only from SGP enzootic area may related to a risk for re-introduction to SGP free regions or countries as countries of European Union "EU"(EFSA, 2014). Highly contagious SPPV and GTPV are able to cause very high morbidity (70-90\%) and mortality up to $50 \%$. Young animals show more severe disease, and mortality in lambs and kids may be as high as 100\% (Rao and Bandyopadhyay, 2000).

\section{Host range}

Sheep is the natural host (Singh et al., 1979). All breeds of sheep and goats either domestic or wild can be affected with pox disease; however some strains are restricted to one species only. Introduced breeds of European or Australian origin are more susceptible than Native breeds in endemic areas (OIE, 2008b). SPPV is more severe in young lambs (4-8 months) than adult sheep and newborn lambs (Yashpal et al.,1997), the influence of sex is concerned, both sexes affected, female of 6-month-old highly susceptible to infection than males (Murthy and Singh, 1971). Crossbreeds sheep have been reported to be generally more resistant compared to the pure breed (Prasad et al., 1995), but in Israel crossbreed sheep were more affected (Yeruham et al., 1998). Factors which related to host as (age, sex, breed, nutritional and immunological status), and to agent including (strain, virulence, pathogenicity), also environment, poor management, starvation and insufficient veterinary services have direct effect on the epizootiology of sheep pox (Woldemeskel and Ashenafi, 2003). Migration and ovination may also spread disease (Bhanuprakash, 2001).

\section{Transmission}

\section{Direct transmission:}

The main mode of transmission of SPPV is occur between an infected and susceptible animal. Animals develop pox lesions in the mucous membranes of the mouth, nasal cavities and conjunctiva, are excreting the virus in saliva and ocular and nasal discharge. The virus is spread in aerosols/droplets via coughing, sneezing, head shaking, vocalizations and breathing. Native animals acquire the virus via inhalation, orally or via skin abrasions (Babiuk et al., 2008). Mechanical transmission can occur by insect vectors (Kitching and Mellor, 1986), Vectors as, stomoxys calcitrans (stable fly) and tsetse fly can transmit virus mechanically (Webbs, 1980). No transmission was detected by biting (Mallophaga spp.), sucking lice (Damalinia spp.), sheep head flies 
(Hydrotaeairritans) and midges (Culicoidesnubeculosus), even though virus could be isolated from previously infected sheep, which was the host for feeding of the a formentioned flies. There is no evidence that SPPV can replicate in arthropod vectors (Mellor et al., 1987).

\section{Indirect transmission}

Virus in saliva, ocular and nasal discharge, skin lesions, scabs, urine and feces may contaminate feed, water, wool and the environment that was leading to an indirect transmission of the virus either orally or via skin abrasions (Rao and Bandyopadhyay, 2000). Untreated skins, hides and wool collected from infected animals may contain viable virus, therefore, they may be a source of infection for native sheep and goats (Rao and Bandyopadhyay, 2000). Vertical transmission from ewe to lamb or doe has been reported in Ethiopian Sheep and Goat (ESGPIP, 2009). Viral transmission via semen or embryos is unknown (CABI, 2015).

\section{Pathogenesis}

Incubation period of sheep pox virus is 4-8 days and of goat pox virus is $4-15$ days. The virus has high affinity to epithelial tissues hence replicates locally in the tissues after entrance to the host cell from this point the virus is classified as epitheliotropic virus. On the $7^{\text {th }}$ day post-inoculation, the virus titer reached to its peak. After 3-4 days of primary viremia the virus spread to the regional lymph nodes to blood. The viremia spread in the body, and affect spleen, lungs and liver. Inhalation of the virus causes lung lesions. Virus titers decreased with the development of serum antibodies from $7-14$ days after infection (OIE, 2012). Signs, on the affected animals within 24 hours from appearance of generalized papules, are conjunctivitis, rhinitis and enlargement of all the superficial lymph nodes, especially the prescapular lymph nodes. Excessive salivation can also occur after infection (OIE, 2012). Stages of development of pox virus infection are five stages: First stage is roseola in which skin lesions typically begin with small red spots within 3 days of infection followed by papules and fever. The second stage is papules which develop after 3 days of roseola stage. The third and fourth stage is vesicles and pustules formation which develop after 3 days of vesicular stage. The last stage of pox lesion is scab formation. Isolation of SGPV following by quantitative analysis using real-time PCR show high viral loads in skin (Bowden et al., 2008).

\section{Clinical signs:}

Both sheep and goat pox have similar clinical sign (Kitching and Taylor, 1985). The first signs appear is rise in temperature (41 to $42^{\circ} \mathrm{C}$ ) (Daoud, 1997). The clinical sign of sheep pox can be either malignant or benign. The 
malignant form of sheep pox is mostly common in lamb. (House, J.A., 1992). This form is the most common type. There is prostration, high fever, marked depression, and discharges from the eyes and nose. Lesions occur on un-wooled skin and on the buccal, respiratory, digestive and urogenital tract mucosa. They appear as papules, then become nodular, occasionally become vesicular, pustular and finally scab. Rare to found Pox lesions in the heart muscles in this form of the disease (Radostits et al., 2006). Benign form of sheep pox charachterize only by skin lesions that occur particularly under the tail. This form of sheep pox is common in adult. systemic reaction not found and the animal recovers in one month. Pneumonia and abortion are the complication of SGPV (Iran Veterinary Organization, 2014). In young animals, the mortality rate may reach $100 \%$ while the overall mortality may be $50 \%$ of the flock. Lesions may be seen on the vulva, prenium, nostril and mucous membranes of the mouth. If lesions are present in the lung acute respiratory distress occurs (Ausvetplan, 1996).

\section{Post mortem lesions:}

P.M lesions of SGPV can develop in lung, spleen, lymph node and other internal organs. Also found in the mouth, nares, eye or eyelid. Mucous membranes of affected organ may become ulcerate or slough and necrotic. (CFSPH,
2008). Lesions of pox virus included in internal organs, especially in the respiratory and digestive tracts (Embury-Hyatt et al., 2012). Lymph nodes draining infected areas are enlarged upto eight times normal size, swollen and may be congested and haemorhhagic (Kitching , 2007). Histologically, changes in epidermal cells occur which include acanthuses, parakeratosis, hyperkeratosis, ballooning and degeneration of proliferating epithelial cells (Rao et al., 1994), cytoplasmic inclusions also found, epithelial hyperplasia and endothelial cell proliferation (Asagba and Nawathe, 1981).

\section{Laboratory Diagnosis:}

Several laboratory confirmation techniques are based on virus isolation and serological tests like immunoflourscence,

immunoprecipitation, virus neutralization and ELISA (Oguzoglu et al., 2006). Methods for differentiation between SPPV from GTPV include restriction endonuclease analysis, sequencing of whole genome and gene-based polymerase chain reactionrestriction fragment length polymorphism (PCR-RFLP) (Hosamani et al., 2004). Because of the close antigenicity between SPPV and GTPV, it is difficult to differentiate these pathogens using virus isolation and serological tests (Balinisky et al., 2008). For detection of CaPVs, there are several molecular assays depend 
on host species specific (Zhixun et al., 2014). Detection of one viral species is the principle of most of these tests (Zhou et al., 2012). Multiplex PCR tests need the use of species-specific primers

(Tuppurainen et al., 2005). Other tests, consumes time for post-PCR processing step (Lamien et al., 2011a). Polymerase chain reaction (PCR) followed by sequencing is considered a rapid, sensitive and good specific technique for detection and differentiation of SPPV and GTPV based on the open reading frame genes and also used for genotyping (Zhu et al., 2013).

Prevention and control of sheep and goat pox

For control and eradication of SGP virus, national programs must be done and this need, firstly reporting system, vaccination of the veterinary infrastructure, technology and financial resources (Breeze, 2006). International trade in animal and their products will compensate costs of control and eradication of SGP (Bhanuprakash, V., 2011). Modified live vaccine used for protection of sheep and goat pox. Romanian strain vaccine has been used effectively for many years for the control of sheep and goat pox (OIE, 2012). Animals of all ages are recommended to be vaccinated, lambs and kids should be vaccinated annually, at 3-4 month of age, as the maternal antibody has disappeared. Ring vaccination is frequently practiced during outbreaks in enzootic areas, but usually only the species that are clinically affected are vaccinated (Carn, 1993).

Control strategies of vaccination in Egypt:

In Egypt, three CaPVs (SPPV, GTPV, LSDV) were endemic and appeared either in sporadic or in an outbreak case (Aboul-Soud et al., 2018). So, control of the diseases depends mainly on a laboratory diagnosis that followed by a quarantine application, in addition to a vaccination is considered the most easy and effective protection way against all CaPVs diseases (Bhanuprakash V.,2011).

In Egypt, a trivalent vaccine that composed of SPPV strains (Romanian, Kenyan 0180) and GTPV vaccine with an equal volume and nearly equal titre used as abroad-spectrum vaccine against all CaPVs diseases. That vaccine gives a remarkable high immunity compared with commercial RSPPV vaccine alone (Christine, 2012).

SPPV and GTPV vaccines do not replicate in small animals' models to evaluate its efficacy, so the evaluation of the vaccine in its preferable and specific host is the first step to detect the efficacy of the vaccine experimentally and in field application. Kenyan SGP O108 vaccine used to immunize both small ruminant and cattle against CaPVs with remarkable success (OIE, 2012).

Trivalent CaPVs vaccine give a good immune response based on 
both cellular and humoral immunity which represented by the induction of higher level of lymphocytes proliferation and Abs titer respectively, in addition to a high safety degree on pregnant dams and ability to provide relative long protective passive immunity to new-born lambs and kids than the commercial RSPPV vaccine (Eman et al., 2019).

No vaccines are available against CaPVs used to differentiate between infected and vaccinated Animals (DIVA) test. All the currently used vaccines are manufactured using primary cells, which make quality assurance difficult and can cause issues with endogenous agents (Babiuk et al., 2008).

Trivalent vaccine should be used in vaccination of lambs and kids at 2.5 month of age to avoid the reoccurrence of outbreak. Due to the close antigenic relationship between genus CaPVs strains so we recommend to use this trivalent vaccine as new candidate in Egypt to control reoccurrence of LSD in cattle with further study to evaluate its efficacy on long term (Eman et al., 2019).

CaPVs strains share a major neutralizing site; consequently, it is possible to protect cattle against LSD using strains of CaPVs derived from either sheep or goats as used in egypt by using Romanian sheep pox (RSPPV) vaccine. Southern Africa is devoid from SPPV and GTPV so only attenuated LSD vaccine are used, but in northern, central Africa and in the Middle East SPP, GTP and LSD viruses are endemic. SPP vaccines in attenuated form such as, KSGP O240, RM65 and Romanian SPPV strains have been used against LSD (Somasundaram et al., 2011).

In Egypt, it was reported that the live attenuated RSPPV vaccine did not provide cattle with complete protection against LSD and reoccurrence of an outbreaks in vaccinated animals (Salib and Osman, 2011), but goats vaccinated with RSPPV vaccine are fully unsuccessful (Abu-Elzein et al.,2003).

\section{References}

Aboul-Soud, E.A.; Kafafy, M.H.; El-Suall, S.A.; Zaghloul,M.A. and Christine, A., Mikhael (2018): Preparation of trivalent vaccine against lumpy skin disease using different capripox viral strain. International J. of Vet. Science and Medicine 2018 (inpress).

Abu-Elzein, E.; Housawi, F.and Ramadan, O. (2003): Observations on natural and experimental infection of sheep and goats with a virulent field Capripoxvirus with high affinity to goat. Vet. Arhiv. 2003; 73(3):119-31.

Amal, M. A. Raof; Shahein, M. A. and Hoda, Abd El Monem (2008): Egypt. J. Comp. Path. \& Clinic. Path. Vol. 21 No. 1 (January) 2008; 15- 30. Virology DepartmentBiotechnology Department-Animal Health Research Institute-DokkiGiza. 
Animal Health Australia (AHA) (2011): Disease Strategy Sheep pox and goat pox, Available at: www.animalhealth australia.com.au/programs/ emergency-animal-disease preparedness /ausvetplan/.

Asagba, M.O.and Nawathe, D.R. (1981): Evidence of sheep pox in Nigeria. Trop. Anim. Health Prod. 1981; 13(1):61.

Ausvetplan (1996): Australian Veterinary Emergency Plan. Disease a Strategy, Lumpy skin disease.

Babiuk S, Bowden TR, Boyle DB, WallaceDB, Kitching RP. (2008): Capripoxviruses: An Emerging Worldwide Threat to Sheep, Goats and Cattle. Transbound Emerg. Dis. 2008; 55(7):263-72.

Balinsky, C.A.; Delhon, G.; Smoliga, G.; Prarat, M.;French, R.A.; Geary, S.J.; Rock, D.L. and Rodriguez, L.L.(2008): Rapid preclinical detection of sheep pox virus by a Real-time PCR assay. J. Clin. Microbiol., 46: 438-442.

Bhanuprakash V. (2011): Prospects of control and eradication of capripox from the Indian subcontinent: A perspective. Antiviral Res 2011; 91: 225-32.

Bhanuprakash, V. (2001): Epidemiology of sheep pox infection in Karnataka, the analysis of viral protein profiles of field and vaccine strains and evaluation of live attenuated vaccines. $\mathrm{PhD}$ Thesis. Uni. Agri. Sci. Bangalore, Karnataka, India; 2001.
Bowden, T. R.; S. L. Babiuk; G. R. Parkyn; J. S. Copps; and D. B. Boyle (2008): Capripox virus tissue tropism and shedding: aquantitative study in experimentally infected sheep and goats. Virology 371, 380-393.

Breeze, R.G. (2006): Technology, public policy and control of transboundary livestock diseases in our lifetimes. Revue scientifique et technique (International Office of Epizootics), 25: 271-292.

Carn, V.M. (1993): Control of capripoxvirus infections. Vaccine, 11(13):1275-1279; 56 ref.

Centre for Agriculture and Biosciences International (CABI). (2015): Sheep and Goat Pox. Retrieved from http://www.cabi.org/isc/datasheet/ 81537.

CFSPH (2008): The Center for Food Security Public Health, Iowa State University, College of Veterinary Medicine and Institution of International cooperation in Animal Biologics, an OIE collaborating center.

Christine A Mikhael, Olfat E. Nakhla,Namaa A. Mohamed(2017): Study on the capability of a dual Capripox vaccine in protection of cattle against LSD infection. J. of vet medicine res. 2017; 24 (1): 224-33.

Daoud, J.A.H. (1997): Sheep pox among Australian sheep in Jordan. Tropical Animal Health and Production, 29: 251-252.

Davies, F.G. (1981): Sheep and Goat pox. In: Virus diseases of food 
Animals. London: Academic Press. pp: 733-748.

Diallo, A. and Viljoen, G.J. (2007): Genus Capripoxvirus. In: Mercer, A.A., Schmidt, A. and Weber, O., editors. Poxviruses. Birkhauser, Basel, Switzerland. p167-181.

EFSA, (2014): EFSA Panel on Animal Health and Welfare. 2014.

Elshazly A.G. and Youngs C.R. (2019): Feasibility of utilizing advanced reproductive technologies for sheep breeding in Egypt. Egyptian Journal of Sheep \& Goat Sciences, Vol. 14, No. 1, P: 39 52, April 2019.

Eman, B. AbdElfatah; Mamdouh, F. El-Mekkawi ; Emad, A. Aboul-Soud; Elshaima ,M. Fawzi and Sherif A. ElSoally (2019): Immunological response of a new trivalent capripoxvirus vaccine in pregnant ewes and does. Slov. Vet. Res. 2019; 56 (Suppl 22): 445-55 Original Research Article DOI 10.26873/SVR-782-2019.

Eman, B. Abd-Elfatah; Mamdouh F. El-Mekkawi; Iman $M$. Bastawecy and Elshaima $M$. Fawzi (2018): Identification and phylogentic analysis of sheep pox during an outbreak of sheep in Sharkia Governorate, Egypt. Genet. Mol. Res. 17 (2): gmr.16039901.

Embury-Hyatt C.; Babiuk S.; Manning L.; Ganske S.; Bowden T.R.; Boyle D.B. and Copps J.(2012): Pathology and viral antigen distribution following experimental infection of sheep and goats with capripoxvirus. Journal of Comparative Pathology, 146, 106115.

Ethiopia Sheep and Goat Productivity Improvement Program (ESGPIP) (2009): Technical Bulletin No.29, Sheep and Goat Pox: Causes, Prevention and Treatment.Retrieved from http://www.esg

pip.org/PDF/technical\%20bulletin

$\% 20$ no.29.pdf.

FAO, STAT (2018): Live animals. Downloaded December 5, 2018 from

http://www.fao.org/faostat/en/\#data/ QA

Fenner, E.; Paul, J.G.; Frederick, A. and Michael, J.S. (1996): Veterinary Virology. (2nd edn). Academic Press. Inc.

Garner MG, Lack MB (1995): Modelling the potential impact of exotic diseases on regional Australia. Australian Vet J. 72: 8187.

Hailat, N.; Al-Rawashdeh, O.; Lafi, S. and Al-Bateineh, $\mathbf{Z}$. (1994): An outbreak of sheep pox associated with unusual winter conditions in Jordan. Trop. Anim. Health Prod.,26: 79-80.

Hosamani, M.; Mondal, B.; Tembhurne, P.A.; BandyoPadhyay, S.K.; Singh, R.K. and Rasool, T.J. (2004): Differentiation of sheep pox and goat pox viruses by sequence analysis and PCRRFLP of P32 gene. Virus Genes, 29(1): 73-80.

House, J.A. (1992): Sheep and goat pox. In: Veterinary Diagnostic 
Virology: Practitioners Guide, Mosby Year Book, 217-219.

ICTV (2012): Virus Taxonomy: Ninth Report of the International Committee on Taxonomy of Viruses. (International Committee on Taxonomy of Viruses). Academic Press, London, UK, 1338.

Iran Veterinary Organization (2014): survey analysis on sheep pox and goat pox in IRAN during 2010-2014. Pox National Commitee Bultin of Iran Veterinary Organization, Tehran, Iran.

Khameis, S. Ashraf; lamya, F. Atteya;Ayman, H. Mansour; Heba ,A. Abdelhady and Ashraf, A. Saad (2018): Molecular detection and phylogenetic analysis of sheep pox virus in El Menofiya Governorate. J. of Virol. Sci., Vol. 3: 49- 57, 2018.

Kitching, R. P. and P. S. Mellor (1986): Insect transmission of capripoxvirus. Res. Vet. Sci. 40, 255-258.

Kitching, R.P. (2004): Sheep pox and goat pox. In: Infectious Diseases of Livestock, (Coetzer JAW, 2nd Edn). Capetown: Oxford University Press Southern Africa; pp. 1277-1281.

Kitching, R.P. (2007): Diseases of Sheep, Fourth Edition. 2007; 302306.

Kitching, R.P. and Carn, V.M. (2004): Sheeppox and Goatpox. Office International des Epizooties Manual of Diagnostic Tests and Vaccines for Terrestrial Animals (mammals, birds, and bees). OIE, Paris.

Kitching, R.P. and Taylor, W.P. (1985): Clinical and antigenic relationship between isolates of Sheep pox and Goat pox viruses. Tropical Animal Health and Production 17 (2): 64-79.

Lamien, C.E.; Le Goff, C.; Silber, R.; Wallace, B.D.; Gulyaz, V.; Tuppurainen, E.; Madani, H.; Caufour, P.; Adami, T.; El Harrak, M.; Luckins, A.G.; Albina, E. and Diallo, A. (2011a): Use of the Capripoxvirus homologue of vaccinia virus $30 \mathrm{kDa}$ RNA polymerase subunit (RPO30) gene as a novel diagnostic and genotyping target: Development of a classical PCR method to differentiate goat poxvirus from sheep poxvirus. Vet. Microbiol., 149: 30-39.

Mahmoud, M.A.and Khafagi, M.H. (2016): Detection, identification and differentiation of sheep pox virus and goat pox virus from clinical cases in Giza Governorate, Egypt. Veterinary World. 2016; 9(12):1445-1449.

Maksyutov, R.A.; Gavrilova, E.V.; Agafonov, A.P. and Taranov, O.S. (2013): An outbreak of Sheeppox in Zabajkalskij kray of Russia. Transbound. Emerg. Dis. 62(4): 453-456. https :// doi.org/10.1111/tbed.12176.

Mellor, P. S.; Kitching, R. P. and Wilkinson, P. J. (1987): Mechanical transmission of capripoxvirus and African swine 
fever virus by Stomoxys calcitrans. Res. Vet. Sci. 43: 109-112.

Murthy, D.K.and Singh, P.P. (1971): Epidemiological studies on an outbreak of sheep pox in a mixed flock in Uttar Pradesh. Indian, J. Anim. Sci. 1971;41(11):1072-9.

Nandi S, Rao TVS, Poonam M (1999): Sheep pox - a scourge to sheep indu 6. Abu-Elzein E, Housawi F, Ramadan O. Observations on natural and experimental infection of sheep and goats with a virulent field Capripoxvirus with high affinity to goat. Vet Arhiv. 2003; 73(3):119 31.stry in India. Indian Farming 49: 29-31.

Oguzoglu, T.C.; Alkan, F.; Ozkul, A. and Atalay-Vural S. (2006): A Sheep pox virus outbreak in Central Turkey in 2003: Isolation and Identification of Capripoxvirus. Veterinary Research Communications $30 \quad$ (8): 965971.https://doi.org/10.1007/s11259006-3259-7.

OIE (Office International des Epizooties) (2008a): Peste Des Petits Ruminants. Terrestrial Manual. Pp: 1036-1046.

OIE (Office International des Epizooties) (2008b): Terrestrial animal health code, volume 2, 7th edition.

OIE (Office International des Epizooties) (2012): Sheep pox and goat pox Manual of Diagnostic Tests and Vaccines for Terrestrial Animals, Paris.Chapter2. 2012; 7(14):1-12.
OIE (Office International des Epizooties) (2010): Manual of Diagnostic Tests and Vaccines for Terrestrial Animals, Chapter 2.4.14, Lumpy Skin Disease, Paris: OIE.

OIE (Office International des Epizooties) (2014): Sheep and goat pox - Technical disease card.

OIE (Office International des Epizooties), WAHID (2015): https:// www . research gate.net/ figure/ Geographical distribution of sheep pox and goat pox fig2 283791807.

OIE (Office International des Epizooties) (2000): Manual of standards for diagnostic tests and vaccines.4th ed.; 2000 [chapter 2.1.10].

Prasad, R.P.D.; Rao, M.T.; Charyulu, E.K.and Sreenivasulu, D. (1995): A study on the outbreak of sheep pox in an organized farm. Livestock Adviser 1995; X X (1):32-5.

Radostits, O.M.; Gay, C.C. and Hinchcliff, K.W. (2006): Veterinary Medicine. 10th Edn. SAUNDERS; pp 1430-1431.

Rao, T.V.S. and Bandyopadhyay, S.K. (2000): A comprehensive review of goat pox and sheep pox and their diagnos. Animal Health Research Reviews, 1: 127-136. https://doi.org/ 10.1017/s1466252300000116.

Rao, B.T.; Das, H.J.; Sharma, R.D. and Singh, S.S.S. (1994): Some observations on an outbreak of sheep pox in sheep in East Godavari District, Andhra Pradesh. Livest Advisor 1994; XIX(X):3-6. 
Salib FA, Osman AH. (2011): Incidence of lumpy skin disease among Egyptian cattle in Giza Governorate, Egypt. Vet World. 2011; 4: 162-7.

Senthilkumar V, Thiruna, vukkarasu, M. (2010): Economic losses due to sheep pox in sheep farms in Tamil Nadu. Tamil Nadu Journal of Veterinary and Animal Sciences 6: 88-94.

Sharma, B.; Negi, B.S.; Pandey, A.B.; Bandyopadhyay, S.K. and Shankar,H. (1988): Detection of goat pox antigen and antibody by the CIE test. Tropical Animal Health and Production 20: 109-113.

Singh, I.P.;Pandey, R.and Srivastava, R.N.(1979): Sheep pox: a review. Vet Bull 1979;49(3):145-54.

Soman, J.P. and Singh, I.P. (1981): Determination of optimum conditions for the growth of cell culture attenuated sheep poxvirus. Indian Vet J 1981; 58(1):10-12.

Somasundaram, M.K. (2011): An outbreak of lumpy skin disease in a Holstein dairy herd in Oman:a clinical report. Asian J. of Anim. and Vet. Advan. 2011; 6(8):851-9.

Tulman, E. R.; C. L. Afonso; Z. Lu; L. Zsak; J.-H. Sur; N. T. Sandybaev; U. Z.Kerem -bekova ;V. L. Zaitsev ; G. F. Kutish, and D. L. Rock, (2002):The Genomes of Sheep pox and Goat pox Viruses. J Virol., 76(12): 6054-6061.

Tuppurainen, E.S.; Venter, E.H. and Coetzer, J.A. (2005): The detection of lumpy skin disease virus in samples of experimentally infected cattle using different diagnostic techniques. Onder stepoort J. Vet. Res., 72: 153-164.

USDA. Agricultural bioterrorism act of (2002): Fedl Regist. 67(155): 52383-52389.

Webbs, G. (1980): Sheep and goat pox, transmission of capripoxviruses by various flies indicated the need for a reassessment of the methods of controlling this disease. Annual Report, Institute for Animal Health, Pirbright, UK.

Woldemeskel, M. and Ashenafi, H. (2003): Study on skin diseases in sheep from northern Ethiopia. Dtsch Tierarztl Wochenschr 2003;110(1):20-2.

Yashpal, M.; Mahesh, K.; Batra, S.K.; Puranchand, Malik, Y.and Khatri, M. (1997): Occurrence of sheep pox in unorganized flocks in Haryana State. Indian J. Anim. Sci.; 67:962-3.

Yeruham, I.; Pearl, S.; Abraham, A.and Algazi R. (1998): Simultaneous infections: lambs with contagious ecthyma and sheep pox or contagious ecthyma and papillomatosis. Rev Med Vet; 49(12):1115-20.

Yeruham, I.; Yadin, H.; Van Ham, M.; Bumbarov, V.; Soham, A. and Perl, S. (2007): Economic and epidemiological aspects of an outbreak of sheep pox in a dairy sheep flock. Vet. Rec. 160: 236237.

Zangana, I.K. and Abdullah, M.A. (2013): Epidemiological, clinical, and histopathological 
studies on lamb and kid pox in Duhok, Iraq. Bulgarian J. Vet. Med. 16(2): 133-138.

Zhixun, Z.; Bin, F.; Guohua, W.; Xinmin, Y.; Yingguo, L.; Xiaoli, Z.; Hua, Y.; Xueling, D.; Haixia, Z.; Bo, T.; Jian, L. and Qiang, Z. (2014): Development of loopmediated isothermal amplification assay for specific and rapid detection of differential goat pox virus and sheep pox virus. BMC Microbiol., 14: 10.

Zhou, T.; Jia, H.; Chen, G.; He, X.; Fang, Y.; Wang, X.;Guan, Q.; Zeng, S.; Cui, Q. and Jing, Z. (2012): Phylogenetic analysis of Chinese sheep pox and goat pox virus isolates . Virol. J., 9: 25.

Zhu, X.L.; Yang, F.; Li, H.X. and Dou, Y.X. (2013): Identification and phylogenetic analysis of a Sheep pox virus isolated from the Ningxia Hui Autonomous Region of China. Genetics and Molecular
Research 12 (2):1670-1678. https: //doi .org /10 .4238/2013.may.14.7.

In Egypt both the Romanian

SPP and Kenyan sheep and goat pox (KSGP) virus vaccines

have been used for cattle (Davies, 1991a; Brenner et al.,

2009; Somasundaram, 2011; Abutarbush, 2014).

In Egypt both the Romanian

SPP and Kenyan sheep and goat pox (KSGP) virus vaccines

have been used for cattle (Davies, 1991a; Brenner et al.,

2009; Somasundaram, 2011; Abutarbush, 2014).

In Egypt both the Romanian SPP and Kenyan sheep and goat pox (KSGP) virus vaccines

have been used for cattle (Davies, 1991a; Brenner et al., 2009; Somasundaram, 2011;

Abutarbush, 20 
مراجعة شاملة لفيروسات جلري الأغنام والماعز: منظور لوبائها وأهميتها الاقتصادية في مصر

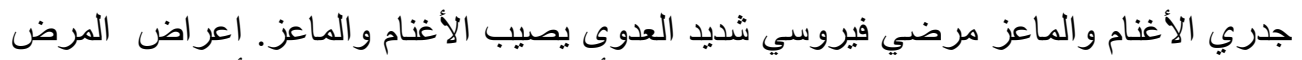

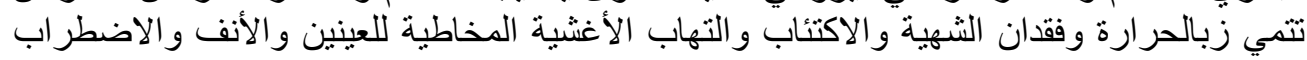

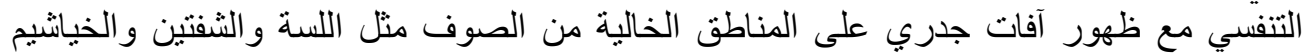

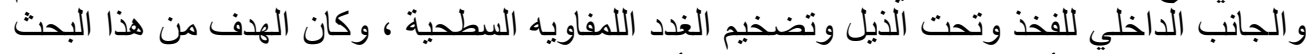

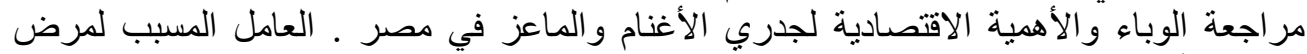
جدري الأغنام و الماعز هو SGPV من عائلة

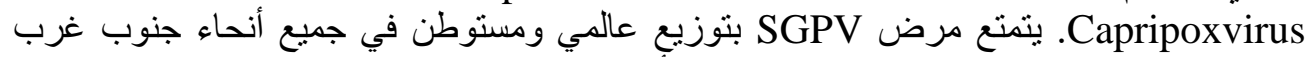

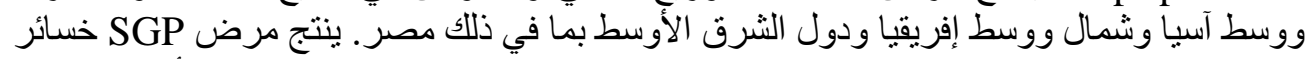

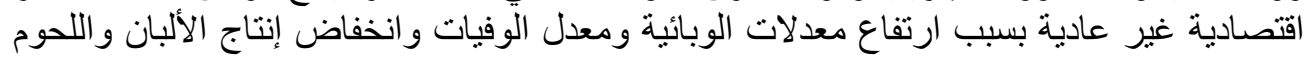

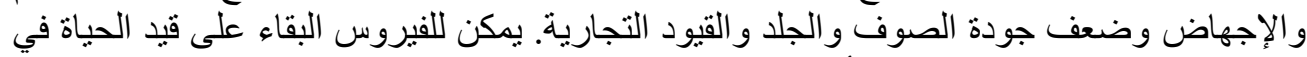

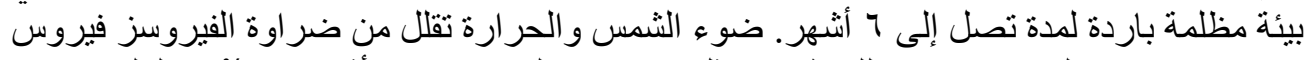

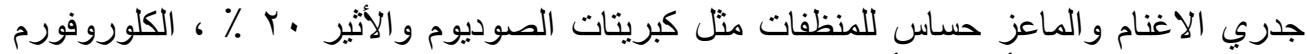

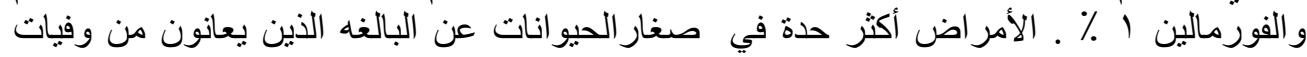

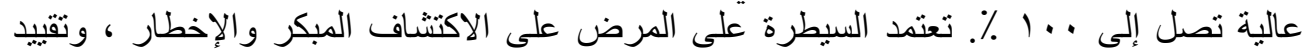
حركة الحيو انات ، و إعدام الحيو انات المصابة و غير الموصلة ، و التطعيم الدائري بلقاح ميت. 